\title{
Investigating the Effectiveness of an Assessment Task through Collaboration in a Bruneian Classroom
}

\author{
Amirudin Haji Damit ${ }^{1}$ \\ Masitah Shahrill2* \\ Roslinawati Mohd Roslan² \\ ${ }^{1}$ Sekolah Menengah Rimba, Ministry of Education, Brunei Darussalam \\ 2Sultan Hassanal Bolkiah Institute of Education, Universiti Brunei Darussalam, Brunei Darussalam \\ *Email: masitah.shahrill@ubd.edu.bn
}

\section{Doi:10.5901/mjss.2015.v6n6s1p214}

\begin{abstract}
Changes in the business world have resulted in the rise in demand for individuals who have successfully acquired the 21 st century skills. Consequently, it is essential for the 21 st century learning to take place in the classrooms. This study investigated the effectiveness of an assessment task in enhancing the students' understanding in mathematics through collaboration. The assessment task came in the form of a project in which the two main objectives were to create a model using recycled materials and a series of questions based on their model. The mathematics topic on Mensuration was selected for this project and the theme was the 'Go Green Project'. The task itself was designed to promote active learning environment, and to foster creative learning in mathematics where the designed model was used to elicit the students' understanding on finding the total surface area and the volume of solids. The task was spread over six mathematics lessons requiring the 25 Year 10 students to work in groups. Thus, enabling the assessment of collaborative skills to take place. Data were collected by means of rubric, students' questionnaires, and pre- and post-tests. The results of the investigation revealed that effective level of collaboration had taken place among students when using the designed assessment task. When students collaborated with one another, their communication skills had improved, fostered their critical thinking and encouraged them to share ideas.
\end{abstract}

Keywords: School-based assessment, Formative assessment, 21st century skills, Collaboration, Secondary

\section{Introduction}

At present, the focus on education has shifted in which we are now more focused on the learning aspect rather than teaching. According to Arendale (1997), a major paradigm shift is occurring in higher education. In addition, after a long period of time of focusing on teaching, there is a healthy shift to focusing on learning. In conjunction with the new educational focus, Brunei Darussalam has implemented a new national education system called the Sistem Pendidikan Negara Abad Ke-21 (or better known as SPN21) in 2008 (Ministry of Education, 2013). In this system, teachers are required to move away from the traditional teacher-centred way of teaching to a student-centred one. Traditional teaching methods emphasised on the teacher giving explanations, examples and exercises with students being passive learners. While a student-centred approach focuses more on students' participation while the teachers' role is more to being a facilitator than just the knowledge transmitter.

According to Wiggins (1989) the student-centred approach enabled teachers to evaluate students according to criteria that were crucial for actual performance for their future. Students were not evaluated based on their memorisation skills as they were assessed in the traditional style. Thus, the students-centred approach is more favourable as it could promote $21^{\text {st }}$ century learning skills among students, which are necessary in preparing them to work in this challenging era. As mentioned by Noweski and colleagues (2012), the $21^{\text {st }}$ century skills were skills and competencies that young people needed to acquire to be effective workers and citizens in the knowledge society of the $21^{\text {st }}$ century. Therefore, SPN21 was introduced in Brunei to facilitate the transition of the teaching methods, from traditional to student-centred method of teaching (Matzin et al., 2015; Ministry of Education, 2013; Shahrill et al., 2013).

Introduced in 2008, the School-Based Assessment (SBA) was part of individual student's overall assessment for the lower secondary level. It was implemented during the interim stage of SPN21, and according to the Hong Kong Examinations and Assessment Authority (2013), SBA involved subject teachers assessing their own students. The new 
SPN21 curriculum involved the integration of the Assessment of Learning (AfL) in which, in AfL, formative assessment was used for evaluation purposes (Botty \& Shahrill, 2015; Curriculum Development Department, 2010; Rashid \& Jaidin, 2014; Sulaiman \& Shahrill, 2014, 2015; Yatab \& Shahrill, 2014a, 2014b). Consequently, it could be argued that the evaluation of students was innovated due to the fact that both the SBA and AfL were introduced for the purpose of supporting the new curriculum (Yatab \& Shahrill, 2014a, 2014b). Meanwhile, in 2010, the integration of the School-Based Assessment and Assessment for Learning resulted in the development of the School-Based Assessment for Learning (SBAfL). The main purpose of SBAfL was to assess how well students had accomplished the objectives and learning outcomes stated in the syllabus. Meanwhile, it was under SBAfL, which resulted in the introduction of the Brunei Common Assessment Tasks (BCATs).

Originally, BCATs were designed by the Curriculum Development Department, Ministry of Education but changes were made in the later years. According to Botty and Shahrill (2015), BCATs were currently created by the appointed teachers within each cluster in which standardisation only took place within the assigned cluster of secondary schools in Brunei. Hence, it was vital for assessment tasks to be monitored in terms of their quality and validity since schools were not using standardised BCATs. It was also crucial to ensure that the designed assessment tasks were conducted in a formative way using formative assessment. The formative side of BCATs was of utmost importance for both students and their parents in terms of giving positive feedback based on the outcomes of the assessment tasks (Botty \& Shahrill, 2015). Therefore, the quality of BCATs should be constantly monitored for the purpose of ensuring that students would progress in accordance to the requirements of SPN21. From there, a major problem associated with the upper secondary level could be identified. This problem was regarding the teaching methods used by the upper secondary level teachers. They seldom used the teaching methods adopted by the lower secondary teachers in their everyday lessons. This was because it is not compulsory for the upper secondary level teachers to carry out BCATs that involved the use of formative assessment. Indeed, it was time consuming to carry out BCATs that consisted of a number of assessment tasks that were formative in nature. A research conducted by Yatab and Shahrill (2014b) found that science teachers had negative perceptions on BCATs. Moreover, the findings revealed that BCATs reduced the teachers' teaching time and this was perceived as an impediment in completing the whole syllabus on time.

According to Morni (2001), all government school teachers in Brunei were prescribed a syllabus guidebook that they adhere to. The mentioned guidebook comprised of lists of topics, lesson objectives and activities for a particular subject. In other words, government school teachers were found to be dependent on the guidebook to teach their lessons. Several researchers in Brunei had highlighted that teachers tended to use teacher-centred approaches to teaching and learning due to the limited time frame they faced in terms of completing the comprehensive syllabus (Jaidin, 2009; Ismail et al., 2015; Shahrill, 2009). Additionally, Khalid (2009) also stated that many teachers appeared to have lack in confidence in using formative classroom assessment.

Although the teachers had been exposed to formative assessment at the higher education level, they were still not used to conduct the assessment effectively. Many efforts have been initiated by the ministry, which included the launch of the $21^{\text {st }}$ Century Teaching and Learning Project in November 2013. This project was aimed at improving students' learning outcomes by enhancing the $21^{\text {st }}$ Century teaching and learning skills of school teachers. Initially, 50 primary and secondary school teachers were involved during the first phase of the project. This subsequently led to a total of about 150 at the third and final phase, with mathematics being one of the subjects of focus (Ko0, 2013; Shahrill et al., 2015; Wood et al., 2014, 2015).

\section{Purpose and Significance of the Research}

The purpose of this study was to investigate the effectiveness of giving an assessment task in enhancing the students' understanding in mathematics through collaboration. The significance of this study was to highlight the importance of the assessment task in helping students to improve their mathematical understanding in the mathematics topic of Mensuration. It was hoped that this study would encourage teachers to utilise and incorporate specifically designed assessment task into their daily teaching, hence enabling effective learning to take place. The assessment tasks would be designed in such a way that enabled the students to develop $21^{\text {st }}$ century skills. This study would focus on designing the assessment task and how students collaborated together by working in a group to complete the task.

Generally, teachers used learning activities only during certain lessons. Nevertheless, the manners in which such activities were conducted still did not truly reflect the level of collaboration that should had taken place among team members. This was especially true in terms of assigning tasks to groups of students who were required to solve problems in mathematics. Collaboration would teach students how to negotiate effectively, improve on their decision making, delegate tasks to other team members, listen to other people's ideas, and integrate ideas in order for the team to 
succeed. This study was hoped to help students build their strong collaboration skill that could be acquired from teamwork, which was needed for their future endeavours.

Apart from that, this study would help students to relate learning mathematics within the collaborative learning model with the real-world mathematics and to develop self-awareness skills among students while doing their group activities. This study would answer the following research questions: How does the assessment task assist students in acquiring the essential collaborative skills? And to what extent does the assessment task help students to improve their performance in mathematics?

\section{Literature Review}

Assessment task plays an important role in the world of education. Such assessment should provide occasional summative feedback on achievement for accountability and other purposes. It is essential for the assessment to be conducted formatively to provide feedback to improve on students' learning. Specifically, they should provide formative feedback to the students and teacher for the purpose of guiding future study (Swan \& Burkhardt, 2013). Previous findings had shown that formative assessment gave a positive impact as an instructional intervention (Black \& William, 2004; Black et al., 2003; Shepard, 2005).

Since formative assessment has proven to be effective by most researchers, upper secondary level teachers should implement it in their everyday lessons. This has a more favourable outcome compared to educators spending precious lesson time, drilling student and rushing to complete the syllabus for the purpose of preparing students for examinations. It was clearly written in the Brunei's curriculum that SBA emphasised on the student-centred approach, which was activity-based. It also "prioritises the learning process and reduces emphasis on exam-oriented instruction" (Curriculum Development Department, 2011, p. 23). In addition, examinations are not considered to be a perfect instrument to measure real students' performance. Mundia (1996) contented that examination often had flaws in various aspects and such exams were known to make errors. The education system in Brunei is still highly prioritising test and examinations with examination being the instrument used in making important selection decisions that affect individual lives (Mundia, 2010). Hence, this results in teachers being more focused on preparing students for examinations instead of developing the essential $21^{\text {st }}$ century skills for future purposes. This represents a contradiction in which teachers are moving away from the Ministry of Education's mission and vision.

Mathematical tasks are considered to be crucial to the learning of mathematics. Chapman (2013) highlighted that mathematics tasks could provide students with the needed stimulus that enabled them to think about particular concepts and procedures. The research conducted by Thanheiser et al. (2014) had indicated that the tasks where students were given the chance to engage did influence the mathematics they learned. According to Swan (2006), there is a growing body of evidence that well-designed tasks, and supporting resources that illustrated these tasks in use, could contribute to the transformation of teaching and learning.

One aspect of ensuring that students were able to complete the tasks assigned to them at the end of the process is by collaborating, instead of doing the task alone. Meanwhile, it is important to point that the $21^{\text {st }}$ century skills comprises of six crucial skills. They are collaboration, knowledge building, self-regulation, real-world problem-solving and innovation, use of ICT for learning as well as skilled communication (ITL Research, 2012a, 2012b). Thus, collaboration is an essential skill that teachers need to inculcate in students (Duraman \& Shahrill, 2014; Duraman et al., 2015; Sulaiman \& Shahrill, 2014, 2015).

Collaborative learning represents an educational approach to teaching and learning that involves groups of students working together to solve a problem, complete a task or create a product. Therefore, for collaboration to take place in the classroom, teachers need to design learning activities that necessitate pair or group work. At times, collaborative learning is misunderstood. This is because such form of learning is not just about getting students to interact with one another, followed by individual students doing their own work. It is also not about having one or two members doing all the work while the remaining members just include their names in the report. For effective collaborative learning to take place, there were conditions that must be met (Laal et al., 2012).

In the $21^{\text {st }}$ Century Learning Design, collaboration is made up of four main elements. They are cooperation with team members, shared responsibility, making substantive decisions together and interdependent students' work. Meanwhile, among the four mentioned elements, the ability to produce interdependent students' work is the highest level of collaboration. This element involves the contribution from all team members. Two level of accountability are involved in most interdependent work, namely: individual and group accountability. Individual accountability is where each team member is responsible for a task that he or she must complete in order for the group to do its work. The later involves all team members working together to produce the final product. This includes planning and negotiation (ITL Research, 


\section{2a, 2012b).}

There are numerous benefits associated with collaborative learning. One of the benefits is related to the mathematical task itself. Mathematical tasks differ in complexity. Kirschner, Paas and Kirschner (2011) defined task complexity as the challenges imposed by a learning task on the limited cognitive capacity of the student. Certain tasks were simple while others might be highly complex in nature. Highly complex tasks, in contrast to simple tasks, required students to invest more mental effort in order to perform the tasks successfully. In this case, when doing highly complex tasks, collaboration represented an advantage. This was because the students had higher confidence level when they work together to complete the highly complex tasks. Students working on their own could only depended on their own limited cognitive ability while, when working in a group, one could rely on the expanded cognitive abilities of their team members (Kirschner et al., 2011). In addition to this, collaborative learning involved students actively exchanging ideas within small groups. This was beneficial as it could increase interest among students (Gokhale, 1995). Furthermore, Johnson and Johnson (1986) mentioned that the existence of persuasive evidence indicating that cooperative teams were able to achieve at higher levels of thought. Students who worked collaboratively were also able to retain information longer than their counterparts who worked silently as individuals. The shared learning provided students with the opportunity to engage in discussions as well as to take responsibility for their own learning (Totten et al., 1991).

Consequently, in order to enhance students' understanding in mathematics, teachers should attempt to promote cooperative learning in the classroom. To be specific, they should involved groups of learners working together to tackle the assigned assessment task. This was supported by Hodara's (2011) study that student collaboration actually had a positive impact on mathematics learning. Moreover, her study showed that highly structured forms of student collaboration were particularly effective for low-achieving mathematics students.

\section{Methodology}

This study adopted a quantitative approach whereby test instruments were used to compare if there was any improvement in the students' performance after the lesson intervention. During the intervention session, an assessment task in the form of group activity was used to identify the students' level of collaboration. The assessment task involved students designing a mathematical model and presenting their ideas during the group presentations. A rubric was used to assess the level of collaboration the students had shown during the lesson. The post-test was given immediately after the lesson interventions to test the students' mathematical understanding. Students were also given a questionnaire to collect additional data in supporting the research.

\subsection{Sample}

This study was based on a convenient sampling. The participants comprised of 25 Year 10 students (10 male and 15 female students; aged between 14 and 16 years old) from the General Programme Science 5 Year track, and one secondary mathematics teacher from a government school in Brunei. Based on the students' mid-year examination results for the year 2014, the results indicated that only 4 out of 25 students (16.0\%) managed to get credit for their mathematics paper. In other words, the mathematics performances for most of them were still below the average. The female teacher who participated in this study has a total of 10 years of teaching experience in mathematics. Before conducting this research, permission was sought from the relevant departments in the ministry.

\subsection{Assessment Task}

For this study, the assessment task came in the form of a project in which the two main objectives were to create a model using recycled materials and a series of questions based on their model. This was large task that involved a number of sub activities. The mathematics topic on Mensuration was selected for this project and the theme for this task was the 'Go Green Project'. The task was designed to promote an active learning environment. It was also designed to foster creative learning in mathematics where the designed model was used to elicit the students' understanding on finding the total surface area and the volume of solids.

The task was spread over six lessons in which it required the students to work in a group. Each group was allowed a maximum number of 4 members. Hence, this task enabled the assessment of collaborative skills to take place. The students' collaboration skills were assessed based on the readily available '21 CLD Learning Activity Rubrics' for the collaboration dimension from ITL research (2012a, pp. 3-9), and the '21 CLD Student Work Rubrics' for the collaboration dimension from ITL research (2012b, pp. 3-9) 


\subsubsection{Rubrics for the Collaboration Dimension}

This research involves the utilisation of the 21 CLD Learning Activity rubric adapted from the ITL Research (2012a, pp. 89) to assess the collaboration skills shown by the group members (see Table 1 below).

Table 1. The 21 CLD Learning Activity Rubric: Elaboration of level of coding for the collaboration dimension

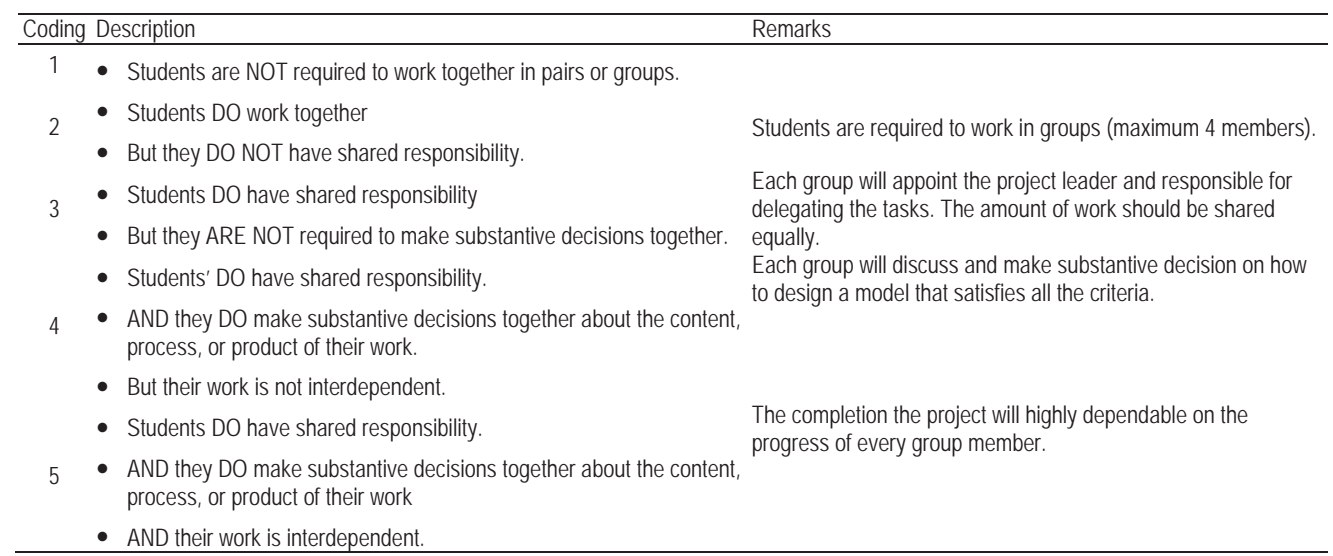

Table 1 shows the elaboration of the level of coding for the collaboration dimension performed by the students during group work. To interpret the coding, if the work does not require the students to work in groups, it will be coded as Code 1. However, if the work does require the students to work in groups and they do not display any shared responsibility in order to develop a common product, design or response, then it will be Code 2 (refer also to ITL Research, 2012a, pp. 39 , for the subsequent decision steps of the coding).

\subsubsection{Pre-test and Post-test}

A pre-test and a post-test were used to measure whether there was any improvement in the students' performance after the intervention session. This involved making comparisons with the results obtained from the pre-test with the eventual post-test that took place after the intervention session. For both pre-test and post-test, the students were given a total of one hour to answer all the questions. They consisted of a series of questions of the concerned topic mensuration, taken from the past year papers or other suitable supplementary resources.

\subsubsection{Questionnaire}

Questionnaires offered an objective means of gathering information about people's knowledge, beliefs, attitudes and behaviour (Boynton \& Greenhalgh, 2004). One advantage of using questionnaires as a research tool is that it could produce generalisable results due to the large sample size. For this research, the use of questionnaires acted as one of the research instrument. The questionnaire consisted of 26 items, comprising of students' response about working collaboratively with peers and the impact of assessment tasks in their learning achievement. It was a 4-point continuous Likert scale type of questionnaire (strongly disagree, disagree, agree, and strongly agree). The questionnaire was tested for its validity and reliability where the Cronbach Alpha for this questionnaire was 0.918 . Upon completion of the intervention session, the questionnaire was administered to the students, followed by the post-test.

\subsection{Data collection}

This study began with the administration of the pre-test. This was then followed by the intervention period, which comprised a total of six lessons. The first lesson began with the subject teacher distributing the project worksheet and explained the outline of the project and the project framework. The teacher did not give any ideas or examples, especially regarding the product of this project. Then, students form their own group, as was the main requirement in order to do the 
tasks. The maximum number of students for each group was four. Team members were based on the students' own choice. After forming their own group, there was a brainstorming session where group members discussed about their project. Furthermore, delegation of tasks among group members was expected to take place.

For the second and the third lessons, the students created their model using the recycled materials of their choice. Their model should be based on the criteria stated in the project outline. At this stage, the students were expected to show their level of collaboration. In the fourth lesson, the students created slides for the respective presentations and a series of questions with respect to the designed model that they have created. Overall, at this stage, each group was expected to complete the model and the accompanying questions.

In the subsequent lesson, all groups submitted two copies of their proposal. This was followed by the group presentation session. Each group was given seven minutes to do their presentation including the feedback session where other group members and the teacher gave their feedback. For the final intervention period, each group attempted to answer the questions created by other groups using the respective models. Upon completion of the lesson intervention, the post-test was executed immediately. Finally, a set of questionnaires was distributed to the students.

\subsection{Data Analysis}

The level of collaboration was analysed based on the video recording, which record most of the classroom activity during the lessons. The video data that was taken throughout the lesson intervention is carefully reviewed and analysed. By using the '21 CLD Student Work rubrics' (ITL Research, 2012b, pp. 3-9), students' level of collaboration could be identified and also used to answer the first research question. Furthermore, descriptive statistics were also used to find the percentage for each code for collaboration. In addition, the data collected from the students' questionnaire was analysed using Pearson's correlation to find the relationship between the assessment task and the collaborative skills.

\section{Results and Discussions}

Based on the results given in Table 2 below, it shows that 4 out of 7 groups of students (57.14\%) are classified under Code 2 in terms of their collaborative work while doing the assessment task. Whereas, the remaining 3 groups (42.86\%) are categorised under Code 5 , which is the highest level of collaboration based on the criteria in the rubric.

Table 2. Frequency of the code on collaboration achieved by the students

\begin{tabular}{|c|c|c|c|c|c|}
\hline Code & 1 & 2 & 3 & 4 & 5 \\
\hline Description & $\begin{array}{l}\text { Students are } \\
\text { NOT working } \\
\text { together in } \\
\text { pairs or groups }\end{array}$ & $\begin{array}{l}\text { Students ARE } \\
\text { working together } \\
\text { BUT they are NOT } \\
\text { sharing } \\
\text { responsibility fairly }\end{array}$ & $\begin{array}{l}\text { Students ARE sharing } \\
\text { responsibility fairly BUT } \\
\text { they ARE NOT making } \\
\text { substantive decisions } \\
\text { together }\end{array}$ & $\begin{array}{l}\text { Students ARE sharing } \\
\text { responsibility fairly AND they } \\
\text { ARE making substantive } \\
\text { decisions together BUT their } \\
\text { work product is NOT } \\
\text { interdependent }\end{array}$ & $\begin{array}{l}\text { Students ARE sharing } \\
\text { responsibility fairly AND } \\
\text { they ARE making } \\
\text { substantive decisions } \\
\text { together AND their work } \\
\text { product IS interdependent }\end{array}$ \\
\hline Frequency & 0 & 4 & 0 & 0 & 3 \\
\hline$\%$ & 0 & 57.14 & 0 & 0 & 42.86 \\
\hline
\end{tabular}

For the groups of students who are classified as Code 2, the problem arose when some of the group members did not share their responsibility equally. This claim was made based on the data collected using the video recording. It could clearly be seen that, during the intervention session, some students hardly participated throughout the lesson. One male student just sat down and observed his other group members doing the assessment task. This took place in almost every lesson. He also rarely talked and discussed with his group members. According to the subject teacher and his friends, he was a very quiet boy who hardly communicated with any teachers or his classmates. However, he did participated during the group presentation.

\subsection{Pre-test and Post-test}

Table 3 below shows the Mean, Standard Deviation and $p$-value for the pre-test and post-test, which are used to measure the students' performance. The result shows that there is a strong evidence indicating that teaching intervention using the assessment task did improve the students' result. This represents the answer to the second research question. It is significant where $p<0.05$, the mean is 7.00 and the standard deviation is 9.424 . 
Table 3. Mean, Standard Deviation and p-value for the students' performance

\begin{tabular}{cccccc}
\hline & Mean & Standard Deviation & T & df & $p$-value \\
\hline Performance & 7.00 & 9.242 & 3.787 & 24 & 0.001 \\
\hline
\end{tabular}

\subsection{Student Questionnaire}

Table 4 shows the students' responses for the selected questionnaire items, designed based on the criteria stated in the rubric for collaboration. Overall, there was a clear indication that a majority of the students agreed (an average of 85.6\%) on the criteria about collaboration whilst doing the assessment task. In conclusion, the findings from questionnaire proved that the designed assessment task did assist the students in attaining the essential collaborative skills.

Table 4. Students' response for the selected questionnaire items on collaboration

\begin{tabular}{|c|c|c|c|c|}
\hline \multirow[t]{2}{*}{ No. Item Description } & Strongly Agree & Agree & Disagree & Strongly Disagree \\
\hline & \multicolumn{4}{|c|}{ Frequency (\%) } \\
\hline 12 Every group member shares responsibility to their own work & 44.0 & 40.0 & 16.0 & 0.0 \\
\hline 13 Every group member makes major decision together during the activity. & 36.0 & 52.0 & 12.0 & 0.0 \\
\hline $\begin{array}{l}14 \text { Every group member depends on each other in doing their own task to } \\
\text { complete the assessment task. }\end{array}$ & 20.0 & 72.0 & 8.0 & 0.0 \\
\hline $\begin{array}{l}15 \text { All group members work together to produce the final product. } \\
21 \text { Every group member shows their responsibility to complete the task }\end{array}$ & $\begin{array}{l}48.0 \\
40.0\end{array}$ & $\begin{array}{l}36.0 \\
40.0\end{array}$ & $\begin{array}{l}12.0 \\
20.0\end{array}$ & $\begin{array}{l}4.0 \\
0.0\end{array}$ \\
\hline
\end{tabular}

Given in Table 5 is the frequency of students' feedback for the selected questionnaire items on the assessment task. The result indicates that most of the students (on average of 92.67\%) agreed on the mentioned items about the assessment task. Moreover, $88.0 \%$ of them agreed that the assessment task improved their knowledge. Apart from that, majority of them (92.0\%) also agreed that there is an increase in their confidence level towards solving mathematical problem.

Table 5. Students' responses for the selected questionnaire items on the assessment task

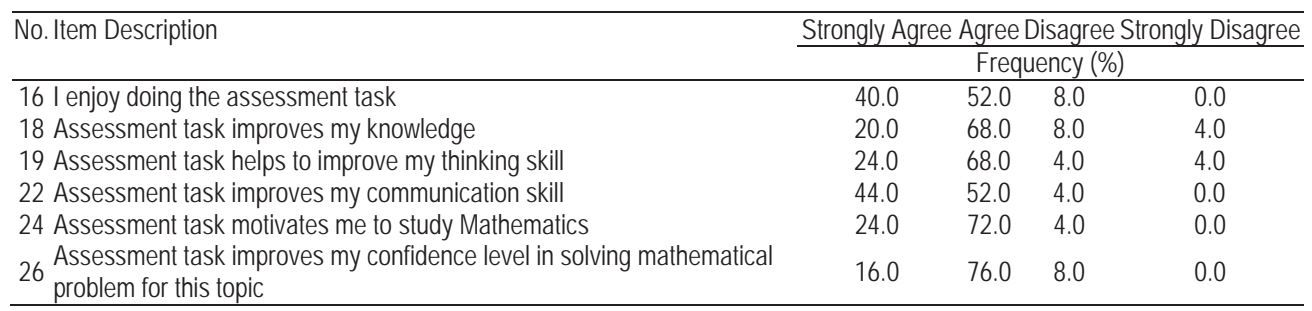

\subsection{Pearson's Correlation}

Presented in Table 6 below is the correlation between Item 18 and Item 26. The result indicates that there is a positive correlation between the assessment task that improves the students' knowledge and the confidence level in solving mathematical problem. It is significant where $p<0.05$. In conclusion, those students who gained knowledge during the intervention session have a greater tendency to be more confident in solving any mathematical problems. Thus, it resulted in an improvement in their performance in mathematics.

Table 6. Correlation between Item 18 and Item 26

\begin{tabular}{|c|c|c|}
\hline \multirow[b]{2}{*}{ Item Description } & & Item 26 \\
\hline & & $\begin{array}{l}\text { Assessment task improves my confidence level in solving mathematical } \\
\text { problem for this topic }\end{array}$ \\
\hline $\begin{array}{l}\text { Item } 18 \text { Assessment task improves my } \\
\text { knowledge }\end{array}$ & $\begin{array}{c}\text { correlation } \\
p\end{array}$ & $\begin{array}{l}.490^{*} \\
0.013\end{array}$ \\
\hline
\end{tabular}

\footnotetext{
* Correlation is significant at the 0.05 level (2-tailed).
} 


\section{Conclusions}

This study revealed that a well-designed assessment task was one of the ways in helping the students acquire and develop the essential collaborative skills. To achieve such skills at the highest level, the students need to fulfil the four main criteria which are cooperation with team member(s), shared responsibility, making substantive decisions together and interdependent students' work. Furthermore, the consistency in working as a group to complete the given task throughout the lessons is crucial to ensure that every student learn the skills. A group work is not consistent when a group consists of group members who did not engaged themselves to participate in their group discussions, and fail to contribute any ideas at certain lessons even though all the team members were involved in giving presentation for their project during the final lesson intervention. This is due to the fact that assessment is made throughout the lessons and not only during the presentation session.

Specifically designed assessment task had successfully assisted the students in acquiring the essential collaborative skills. When the students collaborated with one another, their communication skills improved, as well as encouraged them to share ideas and fostered their critical thinking. Communicating or encouraging students to talk or interact about a given task with their teachers and peers, in the primary and secondary classrooms, have shown to be effective (Mohd Roslan, 2008, 2010, 2014; Othman et al., 2015; Salam \& Shahrill, 2014; Shahrill, 2009; Shahrill \& Clarke, 2014). In addition, it does result in the enhancement of students' creativity. From this study, it was found that there was an improvement in the students' mathematics performance. Furthermore, the students' negative perception of mathematics may be altered as they found it enjoyable to work in groups for the purpose of completing the assessment task. Besides this, using an assessment task during the lessons also resulted in an increase in the students' confidence level in terms of solving mathematical problems.

On the whole, a well-designed assessment task was an important teaching tool as it could help students in improving their mathematics performance and in acquiring the collaborative skills. In this study, the assessment task was a large task that had to be completed in a limited amount of time. Consequently, as students were put in groups, it was necessary for them to delegate the tasks among their group members in order to meet the given deadline. This situation fostered collaboration among students as each student was dependent on their team members to complete the given common assessment task.

Meanwhile, the assessment task also assisted students to improve their mathematics performance. This was because the students were confident in doing the given task. The increase in confidence level was surmised into two factors. Firstly, the students knew what was expected of them because at the start of the lesson, the teacher clearly specified the main objectives of the task to the students. The second factor involved collaborative learning in which working together with their peers meant that they knew they could rely on their team members should they encounter any problem or required any assistance. Likewise, the assessment task was engaging, in which the students were interested in it, in particular the building of the model. This implies that it is crucial for both lower and upper secondary teachers to use assessment task in their teaching since it helps facilitate students' understanding in mathematics. Importantly, the findings in this study more or less echoed previous studies of Botty and Shahrill (2015), Botty, Taha, et al. (2015), Botty, Yusof, et al. (2015), Rashid and Jaidin (2014), Sulaiman and Shahrill (2014, 2015), Tsang and Shahrill (2015), and Yatab and Shahrill (2014a, 2014b).

\section{Implications and Recommendations}

As this was a small-scale study, the collected data was not sufficient to compute the correlation between the assessment task and the students' performance in mathematics using SPSS. A larger sample of students should be used for future study. Moreover, such form of research should be conducted in more than one school and, perhaps, by involving schools in other school clusters in Brunei. Thus, it was not possible to generalise the findings for all secondary schools in this country. Nonetheless, this study implies that the use of formative assessment through collaboration facilitates students' learning in mathematics and fosters critical thinking. The designed assessment task also promoted students' communication skills and provided an avenue for sharing ideas.

\section{References}

Arendale, D. (1997). Leading the paradigm shift from teaching to learning. National Association for Developmental Education Newsletter, 20(3), 1-5.

Black, P., \& Wiliam, D. (1998). Inside the black box: Raising standards through classroom assessment. GL Assessment, London. 
Black, P., Harrison, C., Lee, C., Marshall, B., \& Wiliam, D. (2003). The nature of value of formative assessment for learning. Improving schools, 6, 7-22.

Botty, H. M. R. H., \& Shahrill, M. (2015). A critical review of the school-based assessment in Brunei Darussalam. International Journal of Education and Practice, 3(1), 17-27.

Botty, H. M. R. H., Taha, H. Z. H. M., Shahrill, M., \& Mahadi, M. A. (2015). Connecting students' achievements with attitudes, the teachings and study habit. Mediterranean Journal of Social Sciences, 6(4 S1), 113-119.

Botty, H. M. R. H., Yusof, J., Shahrill, M., \& Mahadi, M. A. (2015). Exploring students' understanding on 'inequalities'. Mediterranean Journal of Social Science.

Boynton, P. M., \& Greenhalgh, T. (2004). Selecting, designing, and developing your questionnaire. British Medical Journal, 328(7451), 1312-1315.

Chapman, O. (2013). Mathematical-task knowledge for teaching. Journal of Mathematics Teacher Education, 16(1), 1-6.

Curriculum Development Department. (2010). School based assessment for learning Brunei Darussalam: SBAfL guidebook for years 7 and 8 core subjects. Negara Brunei Darussalam: Ministry of Education.

Curriculum Development Department. (2011). Framework and guidelines for curriculum and assessment Year 7 and Year 8 core subjects. Negara Brunei Darussalam: Ministry of Education.

Duraman, S. A. H., \& Shahrill, M. (2014). Investigating the snowballing effect technique during group discussions. Paper presented at the at the International Academic Forum (IAFOR) Second Annual Asian Conference on Society, Education and Technology, Osaka, Osaka Prefecture, Japan, 28 October-2 November 2014.

Duraman, H. S. A. H., Shahrill, M., Morsidi, N. M. H. (2015). Investigating the effectiveness of collaborative learning in using the snowballing effect technique. Asian Journal of Social Sciences \& Humanities, 4(1), 148-155.

Gokhale, A. A. (1995). Collaborative learning enhances critical thinking. Journal of Technology Education, 7(1).

Hong Kong Examinations and Assessment Authority (2013). Hong Kong diploma of secondary education examination: Information on school-based assessment. Retrieved from http://www.hkeaa.edu.hk/DocLibrary/Media/Leaflets/SBA_pamphlet_E_web.pdf

Hodara, M. (2011). Reforming Mathematics Classroom Pedagogy: Evidence-Based Findings and Recommendations for the Developmental Math Classroom. CCRC Working Paper No. 27. Assessment of Evidence Series. Community College Research Center, Columbia University.

Ismail, S. F. Z. H., Shahrill, M., \& Mundia, L. (2015). Factors contributing to effective mathematics teaching in secondary schools in Brunei Darussalam. Procedia - Social Behavioural and Sciences, 186, 474-481.

ITL Research. (2012a). 21CLD Learning Activity Rubrics. Retrieved from http://www.itlresearch.com/images/stories/reports/21cld\% 20learning\%20activity\%20rubrics\%202012.pdf

ITL Research. (2012b). 21CLD Student Work Rubrics. Retrieved from http://www.itlresearch.com/images/stories/reports/21cld\% 20student\%20work\%20rubrics\%202012.pdf

Jaidin, J. H. (2009). Conceptions of learning held by upper primary children in government schools in Brunei Darussalam. Unpublished doctoral dissertation, Queensland University of Technology, Brisbane, Australia.

Johnson, R. T., \& Johnson, D. W. (1986). Action research: Cooperative learning in the science classroom. Science and Children, 24, 3132.

Khalid, M. (2009). Improvement of Teaching from Improvement of Assessment Test: Challenges. Retrieved from http://www.criced. tsukuba.ac.jp/math/apec/apec2012/document/document/papers-20_21/Madihah-paper.pdf

Kirschner, F., Paas, F., \& Kirschner, P. A. (2011). Superiority of collaborative learning with complex tasks: A research note on an alternative affective explanation. Computers in Human Behavior, 27(1), 53-57.

Koo, J. S. (2013, November 5). Project aims to enhance teachers' 21 st century skills. The Brunei Times. Retrieved from www.bt.com.bn/news-national/2013/11/05/project-aims-enhance-teachers'-21st-century-skills.

Laal, M., Laal, M., \& Kermanshahi, Z. K. (2012). 21st century learning; learning in collaboration. Procedia-Social and Behavioral Sciences, 47, 1696-1701.

Matzin, R., Jawawi, R., Jaidin, J. H., Shahrill, M., \& Mahadi, M. A. (2015). Brunei lower secondary students' engagement in school and beliefs about the self under the ongoing SPN21 curriculum reforms: Implications for educational and counselling interventions. Journal of Sustainable Development, 8(6), 133-145.

Ministry of Education. (2013). The National Education System for the 21st Century: SPN21 (Revised ed.). Ministry of Education, Brunei Darussalam.

Mohd Roslan, R. (2008). The use of stories and storytelling in primary science teaching and learning. Studies in Education, 12, 79-89.

Mohd Roslan, R. (2010). Analysing teacher-student interactions in a year 6 UK science classroom. Paper presented at the 41st Australian Science Education Research Association, New South Wales, Australia, 30 June-3 July 2010.

Mohd Roslan, R. (2014). Primary teachers' talk in the Bruneian context: representational fluency and consequences for science classrooms. Unpublished doctoral dissertation, University of Queensland, Brisbane, Australia.

Morni, A. (2001). The quality of preschool education in Brunei Darussalam. Unpublished doctoral thesis, University of Exeter, United Kingdom.

Mundia, L. (1996). Psychometric attributes of selected grade ten teacher-made tests from a Papua New Guinea provincial high school. Papua New Guinea Journal of Teacher Education, 3(1), 33-34.

Mundia, L. (2010). Implementation of SPN21 curriculum in Brunei Darussalam: A review of selected implications on school assessment reforms. International Education Studies, 3(2), 119-129. 
Noweski, C., Scheer, A., Büttner, N., von Thienen, J., Erdmann, J., \& Meinel, C. (2012). Towards a Paradigm Shift in Education Practice: Developing Twenty-First Century Skills with Design Thinking. In H. Plattner, C. Meinel, \& L. Leifer (Eds.), Design Thinking Research: Measuring Performance in Context, (pp. 71-94). Springer-Verlag Berlin Heidelberg.

Othman, H. R. H., Suhaimi, Z., Shahrill, M., \& Mahadi, M. A. (2015). To pair or not to pair: Investigating the dynamics of teacher-student interactions in different classroom settings. Paper presented at the $6^{\text {th }}$ International Conference on New Horizons in Education, Barcelona, Spain, 10-12 June 2015.

Rashid, R. A., \& Jaidin, J. H. (2014). Exploring primary school teachers' conceptions of assessment for learning. International Education Studies, 7(9), 69-83.

Salam, N. H. A., \& Shahrill, M. (2014). Examining classroom interactions in secondary mathematics classrooms in Brunei Darussalam. Asian Social Science, 10(11), 92-103.

Shahrill, M. (2009). From the general to the particular: Connecting international classroom research to four classrooms in Brunei Darussalam. Unpublished doctoral dissertation, University of Melbourne, Melbourne, Australia.

Shahrill, M., \& Clarke, D. J. (2014). Brunei teachers' perspectives on questioning: Investigating the opportunities to 'talk' in mathematics lessons. International Education Studies, 7(7), 1-18.

Shahrill, M., Mahalle, S., Matzin, R., Hamid, M. H. S., \& Mundia, L. (2013). A comparison of learning styles and study strategies used by low and high math achieving Brunei secondary school students: Implications for teaching. International Education Studies, 6(10), 39-46.

Shahrill, M., Wood, K., \& Morsidi, N. M. H. (2015). The teaching and learning of mathematics practices in the 21st century: Empowering the need to change. Regular lecture presented at the $7^{\text {th }}$ ICMI-East Asia Regional Conference on Mathematics Education, Cebu City, Philippines, 11-15 May 2015.

Shepard, L. A. (2005). Formative assessment: Caveat emptor. In ETS Invitational Conference, New York, NY.

Sulaiman, N. D., \& Shahrill, M. (2014). The impact of collaboration in the learning of secondary school statistics. Paper presented at the International Academic Forum (IAFOR) Inaugural North American Conference Series for North American Conference on Education, Providence, Rhode Island, United States, 25-28 September 2014.

Sulaiman, N. D., \& Shahrill, M. (2015). Engaging collaborative learning to develop students' skills of the $21^{\text {st }}$ Century. Mediterranean Journal of Social Sciences, 6(4), 544-552.

Swan, M. (2006). Collaborative learning in mathematics: A challenge to our beliefs and practices. London: National Institute for Advanced and Continuing Education (NIACE) for the National Research and Development Centre for Adult Literacy and Numeracy (NRDC).

Swan, M., \& Burkhardt, H. (2012). A designer speaks: Designing assessment of performance in mathematics. Education Designer: Journal Of The International Society For Design And Development In Education, 2(5).

Thanheiser, E., Hillen, A., Olanoff, D., Feldman, Z., Welder, R. M., \& Tobias, J. M. (2014). Task Design in Mathematics Content Courses for Preservice Elementary Teachers: A Collaborative Approach. In M. Martinez, \& A. Castro Superfine (Eds.), Proceedings of the 35th annual meeting of the North American Chapter of the International Group for the Psychology of Mathematics Education. Chicago, IL: University of Illinois at Chicago.

Totten, S., Sills, T., Digby, A., \& Russ, P. (1991). Cooperative learning: A guide to research. New York: Garland.

Tsang, V. H. M., \& Shahrill, M. (2015). Integrating the real-world problem-solving and innovation dimension in the teaching of probability. In C. Vistro-Yu (Ed.), In Pursuit of Quality Mathematics Education for All: Proceedings of the $7^{\text {th }}$ ICMI-East Asia Regional Conference on Mathematics Education (pp. 675-682). Quezon City: Philippine Council of Mathematics Teacher Educators (MATHTED) Inc.

Wiggins, G. (1989). Teaching to the (authentic) test. Educational Leadership, 46 (7), 41-47.

Wood, K., Shahrill, M., \& Asmit, N. A. (2014). How and what must mathematics teachers change to achieve 21st-century outcomes for their students? Paper presented at the World Association of Lesson Studies 10th Annual International Conference 2014, Bandung, Indonesia, 25-28 November 2014.

Wood, K., Sithamparam, S., Jawawi, R., Shahrill, M., Jaidin, J. H., Perera, J. S. H. Q., \& Salleh, S. M. (2015). Teacher action research to develop 21st-century teaching practices and learning outcomes in Brunei. Symposium presentation 'Promoting Equitable Access to 21st-Century Skills: Global and Local Designs for Professional Learning', presented at the Annual Meeting of the American Education Research Association, Chicago, Illinois, United States, April 16-20 2015.

Yatab, R. S., \& Shahrill, M. (2014a). Examining the effectiveness of common assessment tasks in lower secondary science. Paper presented at the $14^{\text {th }}$ Annual Conference ASIA Pacific Science \& Technology Centre (ASPAC 2014), "Building a Community through Science", Brunei Darussalam, 5-8 May, 2014.

Yatab, R. S., \& Shahrill, M. (2014b). The differing views in using the common assessment tasks in secondary school science. International Journal of Science and Research, 3(7), 685-693. 